\title{
Erratum to: Pick of the Year 2014
}

\author{
Bernard Perbal $^{1}$
}

Published online: 10 September 2015

(C) The International CCN Society 2015

\section{Erratum to: J. Cell Commun. Signal. DOI 10.1007/s12079-015-0274-x}

This manuscript was erroneously omitted from issue 1 of 2015. The publisher apologizes for this oversight and for any inconvenience that was caused. The introduction refers to the instructions that the invited authors received in the preparation of their contributions to the following Bits \& Bytes manuscripts published in issue 1 of the Journal of Cell Communication and Signaling:

Dopamine: an old target in a new therapy by Sushanta K. Banerjee (2015)

How IGF-1 activates its receptor by Robert Baxter (2015)

Heparan sulfate provides a mechanism to respond to FGFR2b and control regenerative expansion by Enrique Brandan (2015)

Cancer resistance, high molecular weight hyaluronic acid, and longevity by Gary J. Fisher (2015)

Stem cell quest by Alexandra Irvine (2015)

Lovastatin rescues human and mice cartilage disorders by Satoshi Kubota (2015)

Yin and Yang revisited: CCN3 as an anti-fibrotic therapeutic? By Andrew Leask (2015)

Another dimension to the importance of the extracellular matrix in fibrosis by Laure Rittié (2015)

The online version of the original article can be found at http://dx.doi.org/ 10.1007/s12079-015-0274-x.

Bernard Perbal

bperbal@gmail.com

1 International CCN Society, Nice, France
Therapeutic targeting of the thrombospondin-1 receptor CD47 to treat liver cancer by David D. Roberts, Sukhbir Kaur and David R. Soto-Pantoja (2015)

\section{References}

Banerjee SK (2015) Dopamine: an old target in a new therapy. J Cell Commun Signal 9:85-86. doi:10.1007/s12079-015-0275-9

Baxter R (2015) How IGF-1 activates its receptor. J Cell Commun Signal 9:87. doi:10.1007/s12079-015-0276-8

Brandan E (2015) Heparan sulfate provides a mechanism to respond to FGFR2b and control regenerative expansion. J Cell Commun Signal 9:89. doi:10.1007/s12079-015-0277-7

Fisher GJ (2015) Cancer resistance, high molecular weight hyaluronic acid, and longevity. J Cell Commun Signal 9:91-92. doi:10.1007/ s12079-015-0278-6

Irvine A (2015) Stem cell quest. J Cell Commun Signal 9:93. doi:10. 1007/s12079-015-0279-5

Kubota S (2015) Lovastatin rescues human and mice cartilage disorders. J Cell Commun Signal 9:95. doi:10.1007/s12079-015-0280-Z

Leask A (2015) Yin and Yang revisited: CCN3 as an anti-fibrotic therapeutic? J Cell Commun Signal 9:97-98. doi:10.1007/s12079-015-0281-y

Rittié L (2015) Another dimension to the importance of the extracellular matrix in fibrosis. J Cell Commun Signal 9:99-100. doi:10.1007/ s12079-015-0282-x

Roberts DD, Kaur S, Soto-Pantoja DR (2015) Therapeutic targeting of the thrombospondin-1 receptor CD47 to treat liver cancer. J Cell Commun Signal 9:101-102. doi:10.1007/s12079-015-0283-9 